\title{
De levenslange gevangenisstraf in Engeland en Wales: een reconstructie
}

\author{
R.S.T. Gaarthuis*
}

\section{Inleiding}

In de juridische literatuur is sinds enige tijd debat gaande over de levenslange gevangenisstraf in ons sanctiestelsel en de wijze waarop deze ten uitvoer wordt gelegd. ${ }^{1}$ Kritiek op de huidige regeling laat zich grofweg als volgt samenvatten: de rechtspositie van levenslanggestraften is beneden de maat en de beslissing over nadere modellering van de sanctie gedurende de fase van de tenuitvoerlegging (d.w.z. over eventuele voortijdige beëindiging van de detentie in het kader van de gratiëring) dient uit de administratieve sfeer te worden genomen. Ook de humaniteit zou in het geding zijn. Daarbij wordt veelal opgemerkt dat Nederland een van de weinige landen in Europa is waar levenslang ook daadwerkelijk levenslang lijkt te betekenen.

Interessant gegeven is dat het Nederlandse debat overeenkomsten vertoont met een discussie die een aantal decennia geleden heeft gewoed in Engeland en Wales. Ook daar richtte de kritiek zich op het feit dat levenslanggestraften voor de uiteindelijke duur van hun detentie waren overgeleverd aan de gratie van een administratief orgaan en dat hen ten onrechte de mogelijkheid werd onthouden om de rechtmatigheid van hun detentie te laten toetsen door een onafhankelijke instantie. Een aantal levenslanggestraften beklaagde zich hierover bij het Europese Hof voor de Rechten van de Mens en werd in het

* Remy Gaarthuis doet promotieonderzoek naar de beveiligingsgedachte in het sanctiestelsel en is thans UD straf- en strafprocesrecht aan de universiteit van Tilburg.

1 Zie onder meer W.F. Van Hattum, Het irrationele van de levenslange straf, in: Systeem in ontwikkeling, liber amicorum G.Knigge (Wolf Legal Publishers 2005) p. 231-259; T. Hamer en G.P. De Bont, Levenslang getoetst, in: NJB 2005, p. 2254-2259; H.K. Elzinga en W.F. Van Hattum, Het wetsontwerp voorwaardelijke invrijheidstelling en de levenslange gevangenisstraf, in: NJB 2006, p. 1302-1307; F.W. Bleichrodt, Een leven lang, Oratie Rijksuniversiteit Groningen en het recente rapport van de RSJ Levenslang, perspectief op verandering, december 2006. 
gelijk gesteld. ${ }^{2}$ De Engelse regering zag zich genoodzaakt tot het doorvoeren van een aantal drastische hervormingen.

Dit artikel heeft tot doel de achtergrond van deze jurisprudentie te reconstrueren. In het navolgende zal een licht worden geworpen op de ontwikkeling die de Engelse levenslange gevangenisstraf heeft doorgemaakt sinds halverwege de jaren '60 van de vorige eeuw. Daarbij zal onder meer aandacht worden besteed aan de veranderende maatschappelijke context en de wijze waarop ook het karakter van de levenslange gevangenisstraf door de jaren is mee veranderd. ${ }^{3}$

\section{Discretionary en mandatory life sentence}

Eigenlijk is het niet juist om te spreken over 'de' levenslange gevangenisstraf in Engeland en Wales. Sinds halverwege de jaren zestig kende het Engelse sanctiestelsel namelijk twee soorten levenslange gevangenisstraf voor volwassenen: de zogenaamde discretionary life sentence en de mandatory life sentence for murder. Beide sancties verschilden, wat de wijze van tenuitvoerlegging betreft, aanvankelijk niet wezenlijk van elkaar. Het was gebruikelijk dat de detentie op enig moment werd omgezet naar een invrijheidstelling onder voorwaarden, het zogenaamde 'release on licence' (hierna: VI) ${ }^{4}$ Bij (gerede vrees voor) recidive kon worden besloten de in vrijheid gestelde persoon weer opnieuw te detineren. Het was vooral in de manier waarop ze werden opgelegd, waar de verschillen tussen beide sancties zichtbaar werden. Dit liet zich terugvoeren op hun beider oorsprong. Ze kenden namelijk ieder hun eigen ontstaansgeschiedenis.

De discretionary life sentence was eigenlijk min of meer historisch gegroeid. Ze was een gevolg van het feit dat de Engelse wetgever voor een aantal

2 Zie met name EHRM 2 maart 1987 (Weeks v UK), EHRM 25 oktober 1990 (Thynne, Wilson and Gunnell v. UK) en EHRM 28 mei 2002 (Stafford v. UK).

3 Hetgeen hieronder zal volgen is slechts een grove schets van een in werkelijkheid uiterst complexe ontwikkeling. Een ontwikkeling bovendien die een periode van drie decennia omvat. Niet zal worden ingegaan op de wijzigingen in het Engelse sanctiestelsel als gevolg van de inwerkingtreding van de Criminal Justice Act 2003. Ook blijft buiten beschouwing de kortstondige episode van de zogeheten automatic life sentence uit de Crime (Sentences) Act van 1997.

4 In beginsel bleef de oorspronkelijke 'sentence' van kracht voor de duur waarvoor ze was opgelegd, dat wil zeggen voor het leven. In veel gevallen echter werd een veroordeelde na enige jaren voorwaardelijke invrijheidstelling gratie verleend. 
zware delicten (o.a. verkrachting, doodslag, brandstichting en zogenaamde 'common-law offences') geen strafmaximum had geformuleerd. Het werd aan de rechter overgelaten om vast te stellen welke straf passend zou zijn.

Dat kon voor deze delicten resulteren in een tijdelijke, maar ook in een levenslange straf. De criteria voor toemeting van discretionary life sentences kwamen tot stand in de jurisprudentie van het Court of Appeal. ${ }^{5}$ Zo diende in de eerste plaats sprake te zijn van een delict van een dermate ernstige aard, dat vrijheidsbeneming van lange duur alleen al om die reden zou kunnen worden gerechtvaardigd. Anders dan men op grond van dit criterium zou vermoeden, werd de discretionary life sentence niet primair gezien als middel om de grootst mogelijke mate van afkeur tot uiting te brengen. In tegendeel. Aan de sanctie werd voornamelijk een beveiligende rol toegeschreven, hetgeen onder meer tot uiting kwam in de overige criteria: de sanctie kon slechts worden opgelegd aan delinquenten van 'unstable character, likely to commit serious offences in the future', bij wie bovendien niet op voorhand kon worden ingeschat hoe lang die situatie zou blijven aanhouden.

De ontstaansgeschiedenis van de mandatory life sentence was een heel andere. Deze sanctie kwam in 1965 in de plaats van de verplichte doodstraf voor het delict 'murder'. ${ }^{6}$ Een belangrijke eigenschap van de mandatory life sentence was haar 'gefixeerde' karakter: een veroordeling voor moord ontnam de rechter de mogelijkheid te differentiëren in strafsoort en strafmaat, zodat hij niet anders kon dan levenslang opleggen. Hiermee is ook het verschil in terminologie verklaard. Bij de discretionary life sentence werd oplegging van de sanctie overgelaten aan de discretie van de rechter.

De mandatory life sentence is vanaf het prille begin omstreden geweest. Tijdens de parlementaire behandeling over de wet waarin de afschaffing van de doodstraf gerealiseerd moest worden, is in het House of Lords fel oppositie gevoerd tegen het plan van de regering om de sanctie voor moord een verplicht karakter te geven. ${ }^{7}$ Een van de bezwaren was dat rechters zouden worden gedwongen straffen op te leggen, die zij niet juist achtten. De ene moord immers, zo luidde de redenering, is de andere niet. De regering hield echter voet bij stuk. Het delict moord zou van een bijzondere aard zijn, en

O.a. Hodgson (1968) 52 Cr. App. R. 113 en Pitcher (1979) 1 Cr. App. R. (S) 209.

Murder (Abolition of Death Penalty) Act 1965.

Zie voor een beschrijving L. Blom-Cooper \& T. Morris, With Malice Aforethought (Oxford 2004). 
daarmee ook een bijzondere straf rechtvaardigen. De sanctie zou recht moeten doen aan de uitzonderlijke ernst van het delict, alsmede aan het belang van de maatschappij om zich optimaal beveiligd te achten tegen personen die zich in staat had getoond een ander met voorbedachte raad om het leven te brengen. Het ware daarmee beter om de beslissingsbevoegdheid uit handen van de rechter te nemen en het oordeel over eventueel voortdurende gevaarlijkheid over te laten aan de Home Secretary.

Hierboven is reeds opgemerkt dat de mogelijkheid om op enig moment VI te verlenen, een belangrijk onderdeel uitmaakte van zowel de mandatory life sentence als de discretionaire variant. Met beide sancties werd met andere woorden niet primair beoogd om mensen ook daadwerkelijk de rest van hun leven op te sluiten. In die zin is de benaming 'life sentence' wat ongelukkig gekozen. Engelse auteurs prefereren dan ook vaak de term 'indeterminate sentence', wat zoveel wil zeggen als 'sanctie van onbepaalde duur'.

\section{VI- procedure}

Als we kijken naar de maatschappelijke en politieke context gedurende de periode die hier als beginpunt van de ontwikkeling genomen wordt - grofweg de eerste decennia na de tweede wereldoorlog - dan valt op dat in die dagen een sterk optimisme over de maakbaarheid van mens en samenleving de boventoon voerde. Zo ook in het justitiële beleid. In zowel de straftoemetingspraktijk als in de sfeer van de tenuitvoerlegging uitte deze maakbaarheidsgedachte zich in een beweging richting individualisering. ${ }^{8}$ In het gevangeniswezen domineerde het jargon van 'training and treatment' en de invloed van gedragsdeskundigen nam gestaag toe. De indeterminate sentence - vanwege haar flexibiliteit bij uitstek geschikt voor nadere modellering tijdens de tenuitvoerlegging - won aan populariteit. ${ }^{9}$

8 Zie hierover bijvoorbeeld D.A. Thomas, Principles of Sentencing (London 1970), p. 3 ev.

9 Deze ontwikkeling is prachtig beschreven door D. Garland, Punishment and Welfare (Aldershot 1985). 'Indeterminacy' overigens, kende meerdere gedaanten. Zoals we dadelijk zullen zien introduceerde de Engelse wetgever in 1967 de zogenaamde parole regeling: een administratieve bevoegdheid om gedetineerden veroordeeld tot tijdelijke gevangenisstraffen voorwaardelijk in vrijheid te stellen. Een van de onderliggende gedachten achter deze regeling was dat een gedetineerde op enig moment een 'peak in treatment' zou bereiken, waarna voortduren van detentie enkel nog contraproductief zou zijn. De invoering van de parole introduceerde als het ware een 'onbepaald' element in de tenuitvoerlegging van sancties van bepaalde duur. 
Kort na de tweede wereldoorlog zien we de totstandkoming van de eerste VI-regeling voor levenslanggestraften. ${ }^{10}$ Section 57(1) van de Criminal Justice Act van 1948 maakte het mogelijk om discretionary lifers - anders dan bij gratie - onder voorwaarden in vrijheid te stellen. De beslissing om VI te verlenen kwam bij de Home Secretary te liggen en kon worden aangewend op elk moment de Home Secretary wenselijk achtte.

Toen na afschaffing van de doodstraf in 1965 een nieuwe groep levenslanggestraften ontstond werd ook voor hen in een VI-regeling voorzien. ${ }^{11}$ Het aanvankelijke voornemen van de regering was geweest om ook nu de VIbeslissing over te laten aan de onbeperkte discretie van de Home Secretary. Dit voornemen stuitte echter op weerstand in het House of Lords. De Lords wisten een aantal wijziging af te dwingen in de door de regering voorgestelde regeling, bedoeld om de rol van de rechterlijke macht bij de VI-beslissing te vergroten. In de uiteindelijke regeling zou de Home Secretary weliswaar de beslissingsbevoegdheid blijven uitoefenen, maar diende hij zich, voordat hij tot in vrijheidstelling mocht overgaan, eerst voor advies tot de rechterlijke macht te wenden (het zogenaamde 'dual key' mechanisme). ${ }^{12}$ Rechters kregen daarnaast de bevoegdheid om zich in het vonnis uit te spreken over een wenselijke minimumtermijn. ${ }^{13}$ Beide bepalingen overigens, hadden een enigszins symbolisch karakter. Zowel het rechterlijk advies als de indicatie in het vonnis konden de Home Secretary niet binden.

Pas in 1967, relatief laat dus vergeleken met veel andere westerse landen, werd in Engeland een VI-regeling tot stand gebracht voor gedetineerden veroordeeld tot straffen van tijdelijke duur (parole). ${ }^{14}$ Besloten werd om de voorzieningen met betrekking tot levenslanggestraften op te laten gaan in de systematiek van deze algemene regeling. In de wetgeving van 1967 was onder meer voorzien in de oprichting van een aantal nieuwe administratieve organen ter advisering van de Home Secretary: de zogenaamde Parole Board en de Local Review Committee's binnen de inrichtingen. ${ }^{15}$ Het 'dual key'

10 Ook vóór die tijd was het mogelijk om gedetineerden vervroegd in vrijheid te stellen (het door de Home Secretary uitgeoefende 'royal prorogative of mercy'). Deze bevoegdheid zag echter niet specifiek op levenslanggestraften.

11 Murder (Abolition of Death Penalty) Act 1965.

12 Section 3 van de Murder (Abolition of Death Penalty) Act 1965.

13 Section 2(2) van de Murder (Abolition of Death Penalty) Act 1965.

14 Section 61 van de Criminal Justice Act 1967.

15 Local Review Committee's bestonden in de regel uit de directeur van de inrichting, een probation officer en een lid van de 'Board of Visitors'. De Parole Board diende te be- 
mechanisme uit 1965 bleef gehandhaafd, en werd zelfs uitgebreid. Voortaan diende er ook een positieve aanbeveling te liggen van de Parole Board. Achtte de Board voorwaardelijke invrijheidstelling niet verantwoord, dan gebeurde dit dus ook niet. De Home Secretary, als politiek verantwoordelijke voor het functioneren van de parole, bleef echter wel de eindregie in handen houden. Hem kwam een recht van veto toe: hij kon positieve aanbevelingen naast zich neerleggen.

De Criminal Justice Act van 1967 beperkte zich met name tot regelgeving betreffende de bevoegdhedenverdeling tussen de rechter, Home Secretary en diens adviesorganen. De wijze waarop deze bevoegdheden vervolgens zouden moeten worden uitgeoefend kreeg grotendeels vorm in nadere beleidsregels. Binnen dit kader kristalliseerde het VI-selectieproces zich in de jaren daarop volgend geleidelijk uit tot ongeveer de volgende procedure:

- Het was gebruikelijk dat een rechter zich, na oplegging van een levenslange gevangenisstraf, schriftelijk tot de Home Secretary wendde om hem te informeren over de specifieke omstandigheden van het geval. Daarbij werd een indicatie gegeven van wat de rechter voor een straf zou hebben opgelegd, ware er enkel rekening gehouden met de ernst van het feit en overwegingen van generaal preventieve aard. Deze indicatie werd de zogenaamde tariff genoemd.

- Zo'n drie jaar vóór het verstrijken van de tariff werd het dossier van een gedetineerde ter toetsing voorgelegd aan de Local Review Committee binnen de inrichting. Deze commissie maakte een eerste schifting tussen de kansrijke en kansarme parole aanvragen.

- Het dossier werd, indien kansrijk bevonden, doorgezonden naar de Parole Board. De board stelde - wederom op basis van het dossier een advies op voor de Home Secretary over de mogelijkheden voor vrijlating en daaraan eventueel te stellen voorwaarden.

- Na een laatste consult met de rechterlijke macht, nam de Home Secretary de uiteindelijke beslissing.

schikken over de expertise van ten minste één (voormalig) lid van de rechterlijke macht, een psychiater, iemand met reclasseringservaring en een criminoloog. De Board kende bij oprichting aanvankelijk zestien leden, maar dit aantal is in de jaren daarna sterk gegroeid. Beslissingen werden genomen in kleine panels van drie à vier leden, met wisselende samenstelling. 
De procedure was vormgegeven langs de lijnen van een administratief model. Er was slechts beperkte ruimte voor onafhankelijke rechterlijke inbreng en adviezen waren bovendien bindend noch openbaar. Ook over de criteria voor VI bestond, vooral in de eerste jaren, veel onduidelijkheid. Gedetineerden beklaagden zich erover dat zij niet werden geïnformeerd over de voortgang van hun procedure. Hen werd slechts helemaal aan het begin de mogelijkheid geboden om een gesprek te voeren met een lid van de Local Review Committee. Een afschrift daarvan werd in het dossier gevoegd. Een dossier overigens, dat zij niet mochten inzien. Daarna restte niet anders dan uitzien naar de beslissing van de Home Secretary. Deze beslissing kon zo'n drie jaar op zich laten wachten. Resulteerde het selectieproces in een afwijzing, dan hoefde deze beslissing niet nader te worden gemotiveerd. In de regel werd volstaan met een standaardbrief, waarin de inrichtingsdirecteur de gedetineerde meedeelde dat hij helaas niet voor VI in aanmerking was gekomen.

Vanuit het nu bezien is vooral het gebrek aan procedurele waarborgen stuitend. Toen en daar echter, werd dit eigenlijk niet als problematisch ervaren. Sterker nog, in wetenschappelijke kringen werd deze gang van zaken door sommige auteurs zelfs als iets heel vanzelfsprekends voorgesteld. ${ }^{16}$ De redenering daarbij was dat de veroordeelde het recht had verspeeld om over zijn eigen vrijheid te beschikken. Vervroegde invrijheidstelling was een privilege en niet iets dat men in rechte kon afdwingen. Waarborgen waren daarom overbodig. Ze zouden de effectiviteit van het beslissingsproces bovendien enkel belemmeren.

16 Zie bijvoorbeeld J.E. Hall Williams, Natural Justice and Parole, in: Crim.L.R.(1975), pp. 82-91 en 215-223. 


\section{Kentering}

De procedure zoals die tot dan toe functioneerde voegde zich in zekere zin naadloos in de naoorlogse maatschappelijke verhoudingen. Het vertrouwen in de overheid was groot en een sterk op paternalistische leest geschoeid beleid werd voor lief genomen. Zo ook in de penitentiaire sfeer. Gechargeerd kan men stellen dat in een dergelijk klimaat rechtswaarborgen simpelweg overbodig werden geacht. De overheid had immers het beste met de burger voor.

Dit vertrouwen kwam begin jaren zeventig echter onder druk te staan. Wetenschappers begonnen het nut te relativeren van 'training and treatment' programma's voor gedetineerden en het gevangeniswezen zuchtte onder enorme capaciteitstekorten. Een aanhoudende reeks spraakmakende uitbraken en gedetineerdenoproeren deed bovendien niet veel goeds voor de publieke beeldvorming. De strafrechtspleging raakte in de greep van een pessimistisch 'Nothing Works' sentiment. Een soort ideologisch vacuüm, dat dwong tot een herbezinning op de grondslagen van het stelsel.

De kentering werd het eerst zichtbaar in wetenschappelijke kringen. Bijvoorbeeld in de opkomst van het vanuit de VS overgewaaide 'justice denken'. Auteurs bepleitten een terugkeer naar de kern. Er moest een einde komen aan het straffen om te verbeteren. Dit zou alleen maar willekeur en rechteloosheid in de hand werken. Delinquenten dienden niet langer te worden gezien als louter object van strafrechtspleging (de analogie van een zieke die behandeling behoeft), maar als autonoom individu, als drager van rechten en plichten, als iemand die op zijn verantwoordelijkheden kon worden aangesproken. Terug, met andere woorden, naar de proportionele vergelding, zij het vanuit een liberale gedachte gericht op herstel van humaniteit.

Vanuit deze justice beweging werden begin jaren zeventig de eerste kritische kanttekeningen geplaatst bij de parole regeling zoals die tot dan toe functioneerde. Het feit dat gedetineerden zo goed als geen inbreng hadden in hun procedure, het feit dat er nog altijd veel onduidelijkheden bestonden over wat nu precies de criteria voor parole waren, het feit dat afwijzingen niet werden gemotiveerd en dat er geen beroepsmogelijkheden open stonden, kortom: het administratieve model van VI-verlening kwam halverwege de jaren zeventig ter discussie te staan. Zoals de zaken waren geregeld, paste 
het simpelweg niet langer bij het nieuwe mensbeeld dat opgeld deed: dat van het mondige rechtssubject.

Deze wetenschappelijke kritiek kreeg aanvankelijk moeizaam voet aan de grond. In beleidskringen namelijk, had het wegvallen van het behandelparadigma niet dezelfde (progressief liberale) reactie te weeg gebracht als binnen het wetenschappelijke discours. Het failliet van de maakbare samenleving had daar juist geleid tot een meer pragmatische benadering van de problemen, en daarmee, tot op zekere hoogte, tot een verharding van het klimaat. ${ }^{17}$ Uit de beleidsstukken sprak niet langer het paternalistische 'wij weten wel wat goed voor je is'. Het beveiligende karakter van de detentie, in fysieke zin wel te verstaan, werd nu onderstreept. De juridische structuren die stamden uit de jaren zestig kregen een wezenlijk andere rol toebedeeld. Het flexibele karakter van de indeterminate sentence en de parole regeling werd niet langer gezien als mechaniek dat mogelijkheden bood om het behandelaanbod af te stemmen op de behoeften van de gedetineerde, maar als iets dat kon dienen om gevaarlijke gedetineerden zo lang mogelijk binnen de inrichting te houden.

In de herfst van 1983 deed zich een politieke ontwikkeling voor die het debat over de levenslange gevangenisstraf een belangrijke impuls zou geven. Opgejaagd door hardliners binnen de partij, die in dezelfde periode een discussie over herinvoering van de doodstraf hadden aangezwengeld, had de toenmalige conservatieve Home Secretary Leon Brittan zich op een partijcongres uitgesproken voor een beleidswijziging ten opzichte van de levenslange gevangenisstraf. ${ }^{18}$ Brittan bepleitte een nieuw te voeren beleid, een 'tough approach'. Hij meende dat het gat tussen wat een levenslange gevangenisstraf voor het grote publiek leek en dat wat ze in werkelijkheid was (invrijheidstelling na ongeveer 10 à 12 jaar detentie) moest worden verkleind. Hij stelde in het vooruitzicht zijn bevoegdheden te zullen aanwenden om bepaalde categorieën moordenaars langer achter slot en grendel te houden. Als het aan Brittan lag konden politiemoordenaars, kindermoordenaars en terroristen voortaan ten minste 20 jaar detentie tegemoet zien alvorens zij kans zouden maken op voorwaardelijke invrijheidstelling. Het was tijd, zo stelde hij, om een strikte scheiding door te voeren tussen het oordeel over de mate van schuld en het oordeel over het risico dat een delinquent vertegen-

17 Met name met betrekking tot delicten gepleegd door gevaarlijk geachte delinquenten.

18 Zie daarover o.m. Lord Windlesham, Responses to crime, Vol II: Penal policy in the making (Oxford 1993), p. 316 ev. 
woordigde. Brittan zou zich over het eerste voortaan laten informeren door de rechter. Voor advies over het tweede zou hij te rade gaan bij de Parole Board en de Local Review Committee's. De uiteindelijke beslissing echter (dus over de duur van het tariff gedeelte en de uiteindelijke VI-datum), zo onderstreepte hij, bleef in zijn hand.

Deze wat Brittan noemde 'separation of risk and guilt' was strikt genomen niets nieuws. Een dergelijke gang van zaken lag in feite al besloten in de procedure zoals die door de jaren heen vorm had gekregen. Het belang van de beleidsverklaring van Brittan was echter gelegen in formele status die hij toekende aan de tot dan toe informeel gebleven tariff. Brittan's speech maakte inzichtelijk tot waar de legitimerende kracht van het oordeel over de ernst van de begane feiten strekte. Namelijk, tot aan het verstrijken van het tariffgedeelte van de sanctie ('the period necessary to meet the requirements of retribution and deterrence'). Het voortduren van de detentie voorbij dat moment (de fase 'post-tariff'), werd kennelijk gelegitimeerd op andere gronden - zoals de vermeende gevaarlijkheid van de gedetineerde. En juist dát inzicht, zo zullen we dadelijk zien, bood een handvat om de rationaliteit van de sanctie ter discussie te kunnen stellen.

\section{Life sentences ter discussie}

In de jaren die volgden zien we het debat over de levenslange gevangenisstraf in een stroomversnelling raken. De discussie was niet langer een louter academische aangelegenheid. Het debat verbreedde zich richting de politiek en de Courts of Justice.

De gebeurtenissen in politiek opzicht waren in zekere zin typisch Engels. Een van de merkwaardigheden van het Britse constitutionele bestel is namelijk dat een vast aantal vooraanstaande leden van de rechterlijke macht stemrecht toekomt in het Britse House of Lords (in de parlementaire hoedanigheid wel te verstaan). Hoewel deze zogenaamde Law Lords zich over het algemeen terughoudend plegen op te stellen in de debatten, nemen zij formeel deel aan het wetgevingsproces en kunnen in die hoedanigheid ook hun invloed doen gelden op de totstandkoming van wetten. De inbreng van de Law Lords laat zich met name gevoelen op momenten waarop controversiële strafrechtelijke onderwerpen ter discussie worden gebracht. De levenslange gevangenisstraf, het moge duidelijk zijn, was zo'n controversieel onderwerp. 
Eind jaren tachtig bijvoorbeeld had een aantal Law Lords zich ingezet voor de totstandkoming van de zogenaamde House of Lords Select Committee on Murder and Life Imprisonment. ${ }^{19}$ Deze parlementaire commissie, die was benoemd om helderheid te verschaffen in de juridische afbakening van het delict murder, greep bij de publicatie van haar rapport in 1989 de gelegenheid aan om een aantal vergaande voorstellen ter hervorming van de levenslange gevangenisstraf te bepleiten. ${ }^{20}$ Toen de regering in 1990 haar plannen voor een nieuwe Criminal Justice Act publiceerde, bleek evenwel tot grote verbolgenheid van de Lords, dat volledig voorbij was gegaan aan de aanbevelingen van de commissie. ${ }^{21}$ Wat volgde was een ongekend harde confrontatie tussen vertegenwoordigers van de regering en het House of Lords op dit punt tijdens de parlementaire behandeling. De regering werd gedeeltelijk op de knieën gedwongen: een aantal van de voorstellen van de Select Committee werd alsnog geïmplementeerd, zij het enkel met betrekking tot de discretionary life sentence. ${ }^{22}$

Lobbywerk van de Law Lords was een belangrijke factor in het gebeuren. Het compromis moet echter ook worden bezien in het licht van de jurisprudentiële ontwikkelingen van dat moment. Niet lang na de toespraak van Leon Brittan waren de eerste levenslanggestraften naar de rechter getogen om de rechtmatigheid van hun sanctie, althans de wijze waarop die ten uitvoer werd gelegd en de procedures waaronder dat gebeurde, te betwisten. Het inzicht dat Brittan had verschaft in de dubbele grondslag van de levenslange gevangenisstraf, diende daarbij als juridisch breekijzer. Een reeks procedures voor de nationale in internationale instanties volgde. Interessant was de rol van een aantal invloedrijke penal reform en civil rights organisaties in deze procedures. ${ }^{23}$ Specifieke gevallen die de pijnpunten van de administratieve VI-procedure (de beslissingsbevoegdheden van de Home

19 House of Lords, Report of the Select Committee on Murder and Life Imprisonment, HL Paper 78-I (HMSO London 1989).

20 Over het onderscheid tussen de delicten 'murder' en 'manslaugter' bestond onduidelijkheid, iets wat - met name gezien de consequenties verbonden aan het een of ander - als uiterst onwenselijk werd ervaren.

21 Home Office White Paper, Crime Justice and Protecting the Public, Cm 965 (London HMSO 1990). De Criminal Justice Bill voorzag onder meer in een geheel nieuwe systematiek voor de voorwaardelijke invrijheidstelling van gedetineerden veroordeeld tot tijdelijke straffen. VI van levenslanggestraften bleef buiten beschouwing.

22 Zie voor beschrijving van de politieke ontwikkelingen onder meer Lord Windlesham, Responses to crime, Vol II: Penal policy in the making (Oxford 1993), m.n. Ch 7, 8 en 9.

23 O.a. JUSTICE en Liberty. 
Secretary en het gebrek aan waarborgen) op scherp zetten, werden geselecteerd en doelgericht aangebracht, waarbij de klagers ondersteuning kregen in de vorm van gespecialiseerde juridische bijstand.

De discussie tussen klagers en vertegenwoordigers van de regering verliep steeds min of meer langs dezelfde lijnen. Een aantal levenslanggestraften bepleitte met verwijzing naar de 'Brittan Rules' dat hun sanctie na verstrijken van de tariff in feite slechts nog beveiligend van aard was. Deze wijziging in grondslag zou onvoldoende tot uiting komen in de waarborgen waarmee de tenuitvoerlegging van hun sanctie was omgeven. Immers, nu in de fase post-tariff niet langer de ernst van het feit, maar de gevaarlijkheid van de dader tot uitgangspunt strekte, was ook de legitimiteit van de detentie niet langer een statisch gegeven. In de VI-procedure zoals die tot dan toe geregeld was, schortte het aan mogelijkheden om de rechtmatigheid van (het voortduren van) de detentie periodiek te doen toetsten. De Home Secretary zou bovendien te veel bevoegdheden toekomen in het kader van de vaststelling van de tariff en de uiteindelijke VI-beslissing. Een procedure voor een onafhankelijke instantie zou, gezien de aard van deze beslissingen en belangen die daarmee gemoeid zijn, de voorkeur verdienen.

Vertegenwoordigers van de Home Secretary stelden zich op het standpunt dat de noodzaak tot het treffen van nadere rechtswaarborgen niet aan de orde was. Een delinquent had zijn recht op vrijheid immers verspeeld door zich schuldig te maken aan een zeer ernstig delict. Een levenslange gevangenisstraf was in principe voor het leven. Een 'lifer' kon geen aanspraak maken op voorwaardelijke invrijheidstelling, maar mocht slechts hopen dat dit hem op enig moment zou worden gegund. Niet omdat hij daar een recht op had, maar bij wijze van privilege. Een levenslanggestrafte was met andere woorden overgeleverd aan de gratie van een welwillende overheid. Aan de Brittan Rules zouden geen rechten kunnen worden ontleend. Volgens de Home Secretary waren het slechts richtlijnen van administratieve aard, welke niet raakten aan het formele karakter van de straf.

Klagers boekten hun eerste successen in de sfeer van de discretionary life sentence. ${ }^{24}$ Om te beginnen in de zaak Handscomb uit 1988. ${ }^{25}$ Het betrof een procedure voor het Engelse High Court waarin werd geklaagd over de wijze waarop de Home Secretary diens tariffstellende bevoegdheid had aange-

24 Zie voor een beschrijving van deze jurisprudentie o.a. N. Padfield, Beyond the Tariff (Devon 2002), p. 30-59.

25 Handscomb (1988) 86 Cr. App. R. 59.

64 
wend. ${ }^{26}$ Het hof oordeelde dat de tariff zo'n belangrijk element in de levenslange gevangenisstraf uitmaakte (het markeerde immers het begin van het beveiligende gedeelte in de sanctie) dat de vaststelling daarvan met meer waarborgen zou moeten worden omkleed. Een gedetineerde zou onder andere inzage moeten worden geboden in de stukken, in de gelegenheid moeten worden gesteld om zijn eigen kant van het verhaal voor het voetlicht te brengen, en de Home Secretary zou niet langer mogen afwijken van het advies van de rechter. De uitspraak in Handscomb leidde tot een bijstelling van het beleid van de Home Secretary, maar enkel in het kader van de discretionary life sentence.

Ook het Europese Hof voor de Rechten van de Mens bleek ontvankelijk voor de grieven van discretionary lifers. In twee bijna identieke zaken (Weeks uit 1987 en Thynne, Gunnell \& Wilson uit 1990) oordeelde het hof dat sprake was van schending van artikel 5 lid 4 van het verdrag. ${ }^{27}$ Het Europese hof keek voorbij de formalistische redenering opgezet door vertegenwoordigers van de regering en bezag wat de sanctie in werkelijkheid inhield. Nu er sprake was van een sanctie van deels beveiligende aard, diende er ruimte te bestaan voor toetsing van die gevaarlijkheid door een onafhankelijke instantie. De Parole Board, zo stelde het hof, zou in principe als 'courtlike institution' kunnen gelden, ware het niet dat de Board de bevoegdheid ontbeerde om, als dat nodig zou zijn, de detentie op te kunnen heffen. Bovendien schortte het aan afdoende procedurele waarborgen, daar voor gedetineerden de mogelijkheid ontbrak tot inzage in de dossiers, het niet mogelijk was om de eigen zaak te bepleiten en beslissingen niet werden gemotiveerd.

Het Home Office leek aanvankelijk niet onder de indruk van deze Straatsburgse tik op de vingers. In een formele verklaring naar aanleiding van de uitspraak in Weeks werd gesteld dat de Home Secretary zich zou beraden over de eventuele consequenties. Daar bleef het bij. Ook toen de regering in

26 Een brief afkomstig van de directeur van de inrichting waar klager Handscomb zijn straf uitzat en waarin werd getracht aan Handscomb te verduidelijken waarom hij vooralsnog niet voor de VI-selectieprocedure in aanmerking kon komen, suggereerde dat de Home Secretary bij het vaststellen van diens tariff factoren had meegewogen die niet enkel zagen op de ernst van het feit. Volgens klager doorkruiste de Home Secretary hiermee zijn in 1983 afgekondigde beleid. Het High Court stelde de klager in het gelijk door te oordelen dat de Home Secretary 'unreasonable' had gehandeld. Het hof typeerde de gebrekkige transparantie van de procedure bovendien als 'rather disquiting'.

27 Respectievelijk EHRM 2 maart 1987 (Weeks v UK), EHRM 25 oktober 1990 (Thynne, Wilson and Gunnell v. UK). 
1990 een grondige hervorming van de parole regeling aankondigde, liet zij de regelgeving rond de levenslange gevangenisstraf buiten beschouwing. Deze keuze werd in de memorie van toelichting gerechtvaardigd met verwijzing naar de inmiddels bij de Europese rechter aanhangig zijnde procedure inzake Thynne, Gunell \& Wilson. ${ }^{28}$ Het ware beter die uitspraak af te wachten, aldus de regering. In de wandelgangen van het House of Lords werden echter plannen gesmeed om de regering op andere gedachten te brengen. Leden van de Select Committee werkten hun tot dan genegeerde aanbevelingen uit in een serie amendementen op de voorstellen van de regering. Via deze omweg kregen zij discussie over de levenslange gevangenisstraf alsnog op de agenda. De regering, voorzien van een werkmeerderheid in het House of Commons, was aanvankelijk van zins geweest de amendementen te verwerpen. Daarvan werd echter afgezien toen ook de klagers in Thynne, Gunell \& Wilson door het Europese Hof in het gelijk werden gesteld. De home secretary liet zijn verzet varen. De VI-procedure voor discretionary lifers zou in overeenstemming worden gebracht met de eisen van het Europese Verdrag. ${ }^{29}$

Hoe anders lag dat met betrekking tot de mandatory life sentence. Deze sanctie was als gevolg van haar ontstaansgeschiedenis verweven geraakt met de discussie over de doodstraf. In de perceptie van het grote publiek was het delict 'murder' een uniek delict dat zich kenmerkte door zijn uitzonderlijke ernst ('unique heinousness'). Een rationeel debat over het functioneren van de mandatory life sentence was daarmee moeizaam, zeker ook omdat discussie over de doodstraf bij tijd en wijle opnieuw oplaaide. In dit licht bezien was niet verwonderlijk dat de home secretary er veel aan was gelegen om de zeggenschap over de executie van de mandatory life sentence in eigen hand te houden. Het onderwerp lag in politiek opzicht gewoonweg te gevoelig.

28 White Paper, Crime Justice and Protecting the Public, Cm 965 (London HMSO 1990), p. 32.

29 Zie onder meer section 34 van de CJA 1991. Voortaan zou de rechter zich over de tariff mogen uitspreken in zijn vonnis. De tariff kreeg op die manier de status van een beslissing waartegen in beroep kon worden gegaan. Er mocht niet langer van de tariff worden afgeweken. De wijzigingen voorzagen verder in de oprichting van een nieuwe commissie binnen de Parole Board - de zogenaamde 'discretionary lifer panel' - welke de selectie van discretionary lifers voor haar rekening zou nemen. Dit DLP kreeg de bevoegdheid bindende uitspraken te doen. Ook werden nadere procedurele waarborgen gerealiseerd, waaronder het recht op inzage in de stukken, het recht om de eigen zaak te bepleiten eventueel bijgestaan door een advocaat, en het recht op een gemotiveerde beslissing.

66 
Tijdens de parlementaire debatten in 1990 stelde de regering zich op het standpunt dat de mandatory life setentence zich, qua karakter, niet liet vergelijken met de discretionary life sentence. Bij de sanctie voor 'murder' zou de vergelding overheersen, hetgeen in 1965 ook de reden zou zijn geweest om de rechterlijke keuzevrijheid uit te sluiten. De bestaande VI-procedure kon in een sanctie met een dergelijk karakter volstaan, zo werd volgehouden. Aanpassing werd niet nodig geacht. Aldus geschiedde, waardoor het nieuwe VIregime alleen voor de discretionary life sentence kwam te gelden.

De totstandkoming van de Criminal Justice Act van 1991 markeerde daarmee de geboorte van een duaal VI-stelsel. ${ }^{30}$ De wet creëerde een verschil in rechtspositie tussen categorieën gedetineerden die voorheen in feite als één werden beschouwd. Het onderscheid was bovendien tamelijk willekeurig. De vermeende 'unique heinousness' van murder, de pilaar waarop het verschil in bejegening steunde, liet zich in vergaande mate relativeren. De common law definitie van het delict was ruim en omvatte een rijke variatie aan gedragingen. Dat wil zeggen, niet alleen de lustmoord in koelen bloedde, maar dus ook de levensbeëindiging op verzoek van het door een terminale ziekte getroffen slachtoffer.

In diverse procedures aangebracht door gedetineerden werd dit verschil in rechtspositie op de korrel genomen. De standpunten van partijen verschilden in de kern niet van de posities die eerder waren ingenomen in de procedures rond de discretionary life sentence: kort gezegd, gedetineerden beriepen zich - met verwijzing naar de Brittan Rules - op het (deels) beveiligende karakter van de sanctie, terwijl vertegenwoordigers van de regering haar vergeldende functie in het sanctiestelsel benadrukten.

Zo speelde in 1994 onder meer de zaak Doody, waarin het House of Lords (let wel, dit keer in de hoedanigheid van hoogste nationale rechtscollege) oordeelde dat de wijze waarop de Home Secretary tot vaststelling van de tariff kwam - vanwege het deels beveiligende karakter van de sanctie - geen recht deed aan de 'minimum requirements of fairness' ${ }^{31}$ Hoewel de Lords vooropstelden, gebonden te zijn aan het onderscheid in procedure dat was neergelegd in de Criminal Justice Act van 1991 (de tariffbevoegdheid van de Home Secretary als zodanig bleef dus in stand), oordeelden ze wel dat

30 Zie sections 34 en 35 van de Criminal Justice Act 1991.

31 Doody v. Secretary of State for the Home Department [1994] 1 AC 531. 
gedetineerden voortaan op de hoogte zouden moeten worden gesteld van de tariffaanbeveling van de straftoemetende rechter. Daarnaast zouden gedetineerden in de gelegenheid moeten worden gesteld om hun visie op de zaak (schriftelijk) te doen toekomen aan de Home Secretary. De Home Secretary ten slotte, werd door de Lords verplicht beslissingen, waarmee hij afweek van de judicial view, met redenen te omkleden.

Voor klagers was dit een hoopvol begin. Het voedde de verwachting dat de Europese rechter - anders dan het House of Lords niet gehouden aan het primaat van de wetgever - korte metten zou maken met het formalistische onderscheid tussen mandatory en discretionary life sentences. Deze hoop bleek echter ongegrond. In het kort na Doody gewezen arrest Wynne v. UK, concludeerde het Europese hof dat beide sancties in essentie wel degelijk van elkaar verschilden. ${ }^{32}$ Dit, zo stelde het hof, omdat de mandatory life sentence automatisch diende te worden opgelegd 'as the punishment for the offence of murder irrespective of considerations pertaining to the dangerousness of the offender'. Het feit dat bij de mandatory life setence, evenals bij de discretionary life sentence, ook een tariff werd vastgesteld en het feit dat ook een mandatory lifers in de regel op enig moment in vrijheid werd gesteld, zou hieraan niet afdoen. De klager, die had betoogd dat hem ten onrechte een periodieke toetsing werd onthouden, kreeg nul op het rekest.

Het tij keerde uiteindelijk met de uitspraak in Stafford v. UK, in $2002 .{ }^{33}$ Het Europese hof boog zich in deze zaak over een klacht van een mandatory lifer die op ongeveer dezelfde gronden als Wynne had betoogd recht te hebben op een periodieke toetsing door een onafhankelijke instantie. In een uitvoerig gemotiveerde uitspraak besloot het hof 'om' te gaan. Opgemerkt werd dat de introductie van de mandatory life sentence in 1965 een stap voorwaarts was geweest ten opzichte van de oude situatie toen moordenaars nog ter dood werden veroordeeld. Het progressieve karakter van de regeling echter, was inmiddels door de tijd ingehaald. Gewezen werd onder meer op de voortdurende kritiek op het dualistische VI-stelsel en het feit dat de invloed van de Home Secretary in de sfeer van de tenuitvoerlegging van straffen onmiskenbaar aan erosie onderhevig was geweest. De grote bevoegdheden van de Home Secretary in het kader van de mandatory life senctence verhielden zich volgens het hof niet langer met moderne noties van rechtvaardigheid,

32 EHRM 18 juli 1994 (Wynne v. UK).

33 EHRM 28 mei 2002 (Stafford v. UK). 
openheid en onafhankelijkheid. Het door de regering betoogde verschil in karakter tussen de mandatory life sentence en de discretionaire variant werd, in het licht van bovenstaande, onhoudbaar geacht. Omdat ook de mandatory life sentence een fase 'post tariff' kende, was de klager ten onrechte de mogelijkheid onthouden van een periodieke toetsing door een onafhankelijke instantie.

Met deze uitspraak was een van de laatste belangrijke hindernissen in het hervormingsproces van de levenslange gevangenisstraf in Engeland en Wales genomen. ${ }^{34}$ De VI-procedure rond de mandatory life sentence werd in lijn gebracht met de eisen van artikel 5 lid 4 van het Europese verdrag.

\section{Tot besluit}

Terug nu naar de Nederlandse situatie. Onze levenslange gevangenisstraf kent in feite een soortgelijke structuur als die in Engeland en Wales. Ook bij ons is er sprake van een samengaan van vergeldende en beveiligende elementen. Oplegging behoort slechts tot de mogelijkheden bij veroordeling voor delicten van een uitzonderlijke ernst en heeft, wanneer het zover komt, in de regel langdurige maatschappelijke uitsluiting tot gevolg. Hoe lang die uitsluiting precies zal gaan duren, kan bij de toemeting van de sanctie nog niet met zekerheid worden gesteld. Een beslissing daarover volgt in een later stadium bij koninklijk besluit, genomen op voordracht van de minister van justitie en na advies van onder meer de rechter en het openbaar ministerie. Onze gratieprocedure lijkt, zeker wat de bevoegdhedenverdeling betreft, in sterke mate op de Engelse VI-procedures van vóór 1991. ${ }^{35}$

Parallellen laten zich ook ontwaren in ruimer, maatschappelijk perspectief. Zoals hierboven beschreven ontsproot de discussie in Engeland uit een meer fundamentele heroriëntatie op de uitgangspunten van het sanctiestelsel als geheel. Scepsis over de effectiviteit van 'training en treatment' leidde tot een nadrukkelijker op de gevaarsbeheersing georiënteerde wijze van tenuitvoerlegging. De bestaande juridische kaders bleken in het licht van dat nieuwe

35 De procedure steekt waarborgentechnisch overigens iets steviger in elkaar. Zo dienen beslissingen te worden gemotiveerd (art. 18 Gratiewet) en is ook het advies van de rechter met redenen omkleed (art. 7 Gratiewet). Desalniettemin blijft gegeven dat gratie ook in Nederland een gunst is en geen rechtens afdwingbaar recht. 
paradigma te kort te schieten. In Nederland heeft zich - zij het in minder extreme mate, en ook minder plotseling - een soortgelijke verschuiving in nuances voorgedaan. De nadruk op humaniteit en terughoudendheid, die onze strafrechtspleging zo lang heeft gekenmerkt, en waar ons stelsel tot ver buiten de landsgrenzen bekendheid om genoot, is niet langer een vanzelfsprekendheid meer. Het publieke debat is repressiever geworden en denken in termen van veiligheid en beveiliging heeft stevig postgevat. Het zijn tendensen die ook lijken door te werken in de rechtspraktijk: er wordt vaker, en ook langer vrijheidsbenemend gestraft. ${ }^{36}$

Het debat over de levenslange gevangenisstraf in Nederland is in het licht van deze ontwikkelingen zeer zeker op zijn plaats. Of de Europese rechter ook ten aanzien van onze sanctie tot schending van artikel 5 lid 4 EVRM zal concluderen, zal de tijd leren. ${ }^{37}$ De discussie is in ieder geval aangezwengeld. $\mathrm{Nu}$ maar hopen dat we op de vruchten daarvan niet, zoals in het Engelse voorbeeld, dertig jaar hoeven te wachten.

36 Zie daarover bijvoorbeeld: S. van Wingerden en P. Nieuwbeerta, Ontwikkelingen in de lengte van gevangenisstraffen voor moord en doodslag: een trend naar langere straffen. In: Trema oktober 2006, nr. 8, p. 329-337.

37 Het zwaartepunt in de Nederlandse discussie is, gezien de recente jurisprudentie van het Europese hof niet onbegrijpelijk, komen te liggen op de mogelijke wrijving van onze gratieprocedure met artikel 5 lid 4 van het Europese verdrag. De grote vraag is evenwel of deze jurisprudentie zonder meer op de Nederlandse situatie toepasbaar is. Problematisch in dat opzicht is het gegeven dat onze levenslange gevangenisstraf geen 'tariff' kent: er wordt niet nader gespecificeerd waar de vergelding eindigt en waar de beveiliging begint. Het karakter van de Nederlandse levenslange gevangenisstraf blijft daarmee enigszins ambigue. Niet geheel uit te sluiten is derhalve, dat het Europese hof onze levenslange gevangenisstraf, bij ontbreken van concrete handvatten voor het tegendeel, kwalificeren zal als een vergeldende sanctie (die ontegenzeggelijk ook beveiligende aspecten kent, maar niet voorziet in beveiliging tot voorbij de grenzen van die vergelding), in het licht waarvan de gratieprocedure - als uitzonderlijke administratieve correctie op het anvankelijke rechterlijke oordeel over de ernst van het feit - toereikend is. 